\title{
Effects of Caponization on Expression of Gonadotropin-Releasing Hormone-I and Gonadotropin Subunits Genes in Roosters
}

\author{
Xing Guo, Bangyuan Zhou, Yi Wan, Jun Zhou, Dan Shi, \\ Zhaoyu Geng, Xingyong Chen and Runshen Jiang \\ College of Animal Science and Technology, Anhui Agricultural University, Hefei 230036, P. R. China
}

\begin{abstract}
We evaluated the effects of caponization on mRNA levels of gonadotropin-releasing hormone-I (GnRH-I), gonadotropin subunit and other hypothalamic and hypophyseal peptide genes in male chicken. Thirty roosters ( $25 \mathrm{~d})$ with similar weight were equally divided into the experimental (capons) and control (sham-operated males) groups randomly. Caponization was performed at 28 days of age and birds were slaughtered at 140 days of age. Caponization resulted in increasing levels of luteinizing hormone $\beta(L H \beta)$ and follicle-stimulating hormone $\beta$ (FSH $\beta$ ) mRNA in the pituitary gland and levels of LH and FSH in serum $(P<0.05$ or $P<0.01)$. There were no significant differences in levels of GnRH-I, Gonadotropin releasing hormone receptor (GnRHR), neuropeptide Y (NPY) and Proopiomelanocortin (POMC) mRNA between the two groups. Capons exhibited lower levels of follistatin (FS), estrogen receptor $\alpha(E R \alpha)$ and higher levels of androgen receptor $(A R)$ mRNA in the pituitary gland compared with sham-operated males $(P<0.05)$. These results suggest that increased LH and FSH concentrations in serum and $L H \beta$ and $F S H \beta$ mRNA levels in pituitary after castration are not depended on GnRH synthesis. And changed expression of $E R \alpha, A R$ and $F S$ genes in the pituitary gland may be important components of regulating gonadotropin in capons.
\end{abstract}

Key words: Caponization, $F S H \beta$, GnRH-I, $L H \beta$, rooster

J. Poult. Sci., 53: 58-62, 2016

\section{Introduction}

In avian species, reproduction is controlled by the hypothalamo-pituitary-gonadal (HPG) axis. Hypothalamic gonadotropin-releasing hormone $(\mathrm{GnRH})$ is released into portal blood in a pulsatile fashion and transported to receptors on gonadotrope cells in the pituitary gland and differently regulated the biosynthesis and secretion of luteinizing hormone ( $\mathrm{LH})$ and follicle stimulating hormone (FSH) (Sharp et al., 1990). Two forms of GnRHs (cGnRHI and cGnRH-II) have been identified in avian species (Miyamoto et al., 1984). cGnRH-I fibers project to the median eminence (Van Gils et al., 1993), and immunization against cGnRH-I results in decreased plasma LH (Sharp et al., 1990), suggest that cGnRH-I could regulate the function of gonadotrope in chicken (Maney et al., 1997). However, there is a controversy about whether cGnRH-II can regulate gonadotrope (Sharp et al., 1990; Guémené et al., 1992; Millam et al., 1998; Proudman et al., 2006).

LH and FSH are consists of a common $\alpha$-subunit, while

Received: March 29, 2015, Accepted: July 19, 2015

Released Online Advance Publication: September 25, 2015

Correspondence: R. Jiang, College of Animal Science and Technology,

Anhui Agricultural University, 130, Changjiang West Road, Hefei,

230036, P. R. China. (E-mail: jiangrunshen@ahau.edu.cn) have distinct $\beta$-subunits that confer their biological activity (Terada et al., 1997). Chicken pituitary have a separate population of LH and FSH cells and a different distribution pattern of hormone producing cells than those of mammals (Proudman et al., 1999). Differential synthesis and secretion of LH and FSH while in part dependent on the GnRH signal pattern, also appears to result from the actions of local and gonadal peptide hormones. (Burger et al., 2004). Sun et al. (2012) reported that estrogen receptor $\alpha(\mathrm{ER} \alpha)$ and androgen receptor (AR) are different distributions in gonadotrope cells suggest that the regulating mechanisms of estrogen and androgen on the pituitary hormones secretion are different. Local production of activin and follistatin (FS) appear to stimulate and inhibit secretion of FSH, respectively (Winters et al., 2001).

In chicken, studies have consistently reported that gonadectomy results in an increase in serum concentrations of LH (Wilson and Sharp, 1976; Zadworny and Etches, 1987; Bruggeman et al., 1998) and $\mathrm{LH} \beta$ mRNA levels in pituitary gland (Petrowskl et al., 1993; Terada et al., 1997). However, literature about the effects of caponization on expression of $\mathrm{GnRH}$ and gonadotropin subunit genes is still scarce.

In present study, we wished to investigate the effects of caponization on mRNA levels of $G n R H-I$, gonadotropin subunit, $A R$ and $E R \alpha$ genes to gain insight into the HPG axis 
in chicken. This study also provided the opportunity to investigate the effect of caponization on the expression of $N P Y$ and $P O M C$ genes which have been proposed to modulate the excitability of GnRH neurons (Contijoch et al., 1993; Millam et al., 2002).

\section{Materials and Methods}

\section{Ethical Approval of the Study Protocol}

The study protocol was approved by the Animal Care and Use Committee of Anhui Agricultural University (Hefei, China).

\section{Management of Experimental Birds}

Thirty roosters (Guang-xi Yellow chickens an indigenous breed in China age, 25 days) with similar body weight were divided randomly into two groups of 15: experimental (capons) and control (sham-operated males). Caponization was performed at 28 days of age. Preoperatively, roosters were not given food or water for $12 \mathrm{~h}$. A $1.0-\mathrm{cm}$ incision was made between the two last ribs, and the bilateral testes were removed. All procedures were undertaken under local anesthesia and iodine-alcohol applied to the incision site. All birds were reared in the same house and raised up to $20 \mathrm{wk}$ of age. Food and water were provided ad libitum. At the end of experiment (140 days), blood samples $(5 \mathrm{~mL})$ were collected via the wing vein. After collection of blood samples, animals were anesthetized. Samples were taken from the hypothalamus and pituitary gland and frozen in liquid nitrogen.

\section{Serum Hormone Determination}

Concentrations of LH, FSH, Testosterone (T) and estrogen $\left(\mathrm{E}_{2}\right)$ were measured by ELISA with commercial kits provided by Nanjing Jiancheng Bioengineering Co. Ltd. (Nanjing China). As mentioned in manufacturer instructions the quantitative sandwich enzyme immunoassay technique was employed to detecting hormone concentrations. Purified anti-chicken LH, FSH, $\mathrm{E}_{2}$ and $\mathrm{T}$ polyclonal antibody have been pre-coated onto microtiter plate. Standards or samples solution were added to the appropriate microtiter plate wells and incubated at $37^{\circ} \mathrm{C}$ for $1 \mathrm{~h}$ then washed five times with phosphate-buffered saline containing $0.05 \%$ Tween 20 (PBST). After washing, the biotinylated chicken anti-LH, FSH, $\mathrm{E}_{2}$ and $\mathrm{T}$ polyclonal antibodies were added to wells and incubated at $37^{\circ} \mathrm{C}$ for $1 \mathrm{~h}$. After washing five times with PBST, the microplate was incubated at $37^{\circ} \mathrm{C}$ for $1 \mathrm{~h}$ with Avidin-Horseradish Peroxidase (HRP) conjugate. Colour developed after the addition of the substrate 3, 3', 5, $5^{\prime}$ tetramethylbenzidine (TMB) and the reaction was stopped after 15 mins by adding a sulphuric acid solution and the color change is measured spectrophotometrically at a wavelength of $450 \mathrm{~nm}$. The concentration of $\mathrm{LH}, \mathrm{FSH}, \mathrm{E}_{2}$ and T in the samples is then determined by comparing the optical density (OD) of the samples to the standard.

\section{Quantitative Real-time Polymerase Chain Reaction (qPCR)}

Total RNA of samples from the hypothalamus and pituitary gland was extracted using TRIzol Reagent (Invitrogen, Carlsbad, CA, USA). The purity and concentration of total RNA was determined with an Ultraviolet Spectrophotometer
(Beckman Coulter Inc., Brea, CA, USA). Electrophoresis on $1.0 \%$ agarose gels was used to verify the integrity of RNA. Then, $0.5 \mu \mathrm{g}$ total RNA from hypothalamus samples and 0.8 $\mu \mathrm{g}$ of total RNA from pituitary-gland samples in a final volume of $20 \mu \mathrm{L}$ was used to generate cDNA using an iScript cDNA Synthesis kit (Bio-Rad, Hercules, CA, USA) in accordance with manufacturer instructions. The genespecific primers that we employed are listed in Table 1. qPCR was undertaken with iTaq Universal SYBR Green Supermix (Bio-Rad) using $25-\mu \mathrm{L}$ reaction mixtures with 0.3 $\mu \mathrm{M}$ of each oligonucleotide primer on a Rotor-Gene 6000 Real-time Cycler (Corbett Research, Cambridge, UK). The PCR program comprised a 10 -min activation step at $95^{\circ} \mathrm{C}$ followed by 40 cycles of $10 \mathrm{~s}$ at $95^{\circ} \mathrm{C}, 15 \mathrm{~s}$ at $60^{\circ} \mathrm{C}$ and $20 \mathrm{~s}$ at $72^{\circ} \mathrm{C}$. After cycling, products were melted by increasing the temperature from $72^{\circ} \mathrm{C}$ to $95^{\circ} \mathrm{C}$. Each sample was run in triplicate, negative (without template) and positive control reactions were carried out for each assay. Relative expression levels of candidate genes were analyzed according to the $2^{-\Delta \Delta \mathrm{Ct}}$ method using the glyceraldehyde 3-phosphate dehydrogenase $(G A P D H)$ gene for normalization (Livak and Schmittgen, 2001).

\section{Statistical Analysis}

Data are the mean \pm SEM. Significance was determined using the Student's $t$-test. $P<0.05$ was considered significant. Analyses were undertaken using SAS v9.1 (SAS Institute, Cary, NC, USA).

\section{Results}

The effects of caponization on mRNA levels of GnRH-I, $P O M C$ and $N P Y$ in the hypothalamus are detailed in Table 2. There was no significant difference $(P>0.05)$ in the mRNA levels of GnRH-I, POMC and NPY genes in the hypothalamus between the two groups. Levels of $L H \beta, A R$ and $F S H \beta$ mRNA were 1.95-fold, 1.29-fold and 1.89-fold higher $(P<$ $0.05)$ in capons than in sham-operated males. However, capons displayed significantly lower levels of $F S$ and $E R \alpha$ mRNA in the pituitary gland $(P<0.05)$. There was no significant difference $(P>0.05)$ in the mRNA levels of GnRHR between the two groups (Table 3). After castration, serum concentrations of $\mathrm{LH}, \mathrm{FSH}$ and $\mathrm{E}_{2}$ were increased by approximately $100 \%, 92.6 \%$ and $84.4 \%(P<0.05$ or $\mathrm{P}<$ $0.01)$ and serum concentrations of $\mathrm{T}$ were decreased by approximately $120.7 \%$ (Table 4 ).

\section{Discussion}

In avian species, the hypothalamic NPY and POMC neuronal elements appeared to contact GnRH perikarya and axons, suggesting that they can modulate the excitability of GnRH neurons (Contijoch et al., 1993; Millam et al., 2002). Stansfieid and Cunningham. (1987) reported that the endogenous opioid peptides inhibited LHRH secretion in cockerel. NPY have been shown to stimulate GnRH secretion (Contijoch et al., 1993). We found POMC mRNA content did not affected by castration. We also found no significant differences in NPY mRNA levels between the two groups. This result was supported by Kameda et al. (2001) who 
Table 1. $\quad \boldsymbol{q} \boldsymbol{R} \boldsymbol{T}-\boldsymbol{P} \boldsymbol{C} \boldsymbol{R}$ primers for candidate genes

\begin{tabular}{|c|c|c|c|}
\hline Gene & Primer sequence & Product size (bp) & Reference \\
\hline$G n R H-I$ & $\begin{array}{l}\text { F-GCTTGGCTCAACACTGGTCT } \\
\text { R-CTGGCTTCTCCTTCGATCAG }\end{array}$ & 202 & NM_001080877.1 \\
\hline$N P Y$ & $\begin{array}{l}\text { F-CCTCATCACCAGGCAGAGAT } \\
\text { R-GCTGAAAATCCCATCACCAC }\end{array}$ & 137 & NM_205473.1 \\
\hline POMC & $\begin{array}{l}\text { F-GAGGAAGATGGAGAAGGGTTG } \\
\text { R-TACACCTTGATGGGTCTCCTC }\end{array}$ & 110 & NM_001031098.1 \\
\hline$F S H \beta$ & $\begin{array}{l}\text { F-ACTCACCAGTCTCATCTGTTCA } \\
\text { R-CATTGATTGCTTCCATTGTGAC }\end{array}$ & 220 & NM_204257.1 \\
\hline$L H \beta$ & $\begin{array}{l}\text { F-TAACGGTGGCGGTGGAGAA } \\
\text { R-CCCAAAGGGCTGCGATACA }\end{array}$ & 109 & HQ872606.1 \\
\hline GnRHR & $\begin{array}{l}\text { F-GGTCATCGTCTCCTCCTTCA } \\
\text { R-GGTGAAGAGCCCATAGGTGA }\end{array}$ & 175 & NM_001012609.1 \\
\hline$A R$ & $\begin{array}{l}\text { F-ATTTGGTCTTCAACGAGT } \\
\text { R-GCCACTGGAATAATACTGA }\end{array}$ & 157 & NM_001040090.1 \\
\hline$E R \alpha$ & $\begin{array}{l}\text { F-CTGGGCAAAGAGAGTTCCAG } \\
\text { R-GATTTCCACCATGCCCTCTA }\end{array}$ & 196 & NM_205183.2 \\
\hline$F S$ & $\begin{array}{l}\text { F-GACTGTGGACCTGGGAAGAA } \\
\text { R-GCTTTGAGAAGGGCACACTC }\end{array}$ & 149 & NM_205200.1 \\
\hline$G A P D H$ & $\begin{array}{l}\text { F-CATCACACGGACACTTCAGG } \\
\text { R-ACAAACATGGGGGCATCAG }\end{array}$ & 244 & NM_204305.1 \\
\hline
\end{tabular}

Table 2. Relative expression of GnRH-I, POMC and $N P Y$ genes in the hypothalamus of capons and shamoperated males

\begin{tabular}{lcc}
\hline \multicolumn{1}{c}{ Gene } & Capons & Sham-operated males \\
\hline GnRH-I & $0.96 \pm 0.17$ & $0.82 \pm 0.13$ \\
$P O M C$ & $0.91 \pm 0.19$ & $1.19 \pm 0.20$ \\
NPY & $0.97 \pm 0.18$ & $1.17 \pm 0.14$ \\
\hline
\end{tabular}

GnRH-I, gonadotropin-releasing hormone-I; POMC, proopiomelanocortin; NPY, neuropeptide Y.

Values are the mean \pm SEM.

Table 3. Relative expression of mRNA in the pituitary gland of capons and sham-operated males

\begin{tabular}{lcc}
\hline \hline \multicolumn{1}{c}{ Gene } & Capons & Sham-operated males \\
\hline$F S H \beta$ & $1.04 \pm 0.15^{*}$ & $0.55 \pm 0.07$ \\
$L H \beta$ & $3.28 \pm 0.48^{*}$ & $1.68 \pm 0.34$ \\
$A R$ & $1.42 \pm 0.09^{*}$ & $1.10 \pm 0.10$ \\
GnRHR & $1.01 \pm 0.11$ & $1.00 \pm 0.12$ \\
$E R \alpha$ & $0.33 \pm 0.04$ & $0.75 \pm 0.08^{*}$ \\
$F S$ & $1.59 \pm 0.34$ & $3.62 \pm 0.68^{*}$ \\
\hline
\end{tabular}

$F S H \beta$, follicle-stimulating hormone beta; $L H \beta$, luteinizing hormone beta; $E R \alpha$, estradiol receptor alpha; FS, follistatin. $A R$, androgen receptor; GnRHR, Gonadotropin releasing hormone receptor Values are the mean $\pm \mathrm{SEM} ; * P \leq 0.05$.
Table 4. Serum concentrations of $\mathbf{L H}, \mathbf{F S H}, \mathbf{T}$ and $\mathbf{E}_{\mathbf{2}}$ in capons and sham-operated males

\begin{tabular}{lcc}
\hline \hline \multicolumn{1}{c}{ Item } & Capons & Sham-operated males \\
\hline $\mathrm{LH}(\mathrm{mIU} / \mathrm{mL})$ & $4.11 \pm 0.53^{* *}$ & $2.05 \pm 0.27$ \\
$\mathrm{FSH}(\mathrm{mIU} / \mathrm{mL})$ & $4.45 \pm 0.69^{*}$ & $2.31 \pm 0.50$ \\
$\mathrm{~T}(\mathrm{pg} / \mathrm{mL})$ & $189.0 \pm 23.3$ & $417.3 \pm 57.4^{* * *}$ \\
$\mathrm{E}_{2}(\mathrm{pg} / \mathrm{mL})$ & $19.1 \pm 2.1^{* *}$ & $10.4 \pm 1.3$ \\
\hline
\end{tabular}

LH, luteinizing hormone; FSH, follicle-stimulating hormone; $\mathrm{E}_{2}$, estradiol. T, Testosterone.

Values are the mean $\pm \mathrm{SEM} ; * P \leq 0.05, * * P \leq 0.01$, *** $P \leq 0.001$.

demonstrated that the concentrations of NPY mRNA in chicken hypothalamus remain unaffected after castration. These findings suggest that testicular testosterone is not involved in POMC and NPY regulating GnRH release in roosters.

Gonadal hormones regulate expression of gonadotropin subunit gene by acting at the hypothalamus to alter GnRH pulsatility. Testosterone reduces gonadotrophin subunit mRNAs by inhibiting GnRH secretion (Dalkin et al., 1992); Oestradiol replacement at the time of gonadectomy prevents the rise in LH- $\beta$ mRNA concentrations by altering GnRH secretion (Dalkin et al., 1990). The present study shows that the serum levels of LH in capons increased twofold com- 
pared with sham birds 112 days after castration, parallelly changed levels of $\mathrm{LH} \beta$ mRNA in the pituitary. These results are in agreement with Terada et al. (1997), who reported that ovariectomy increased plasma concentrations of LH as well as $L H \beta$ mRNA levels in the pituitary of chicken. Similarly, caponization resulted in increasing serum FSH concentrations and FSH $\beta$ mRNA levels which is in agreement with Bruggeman et al. (1998) who reported that FSH concentrations significantly increased after ovariectomy in Hybro G broiler breeder (Euribrid, Boxmeer). Additionally, serum concentrations of $E_{2}$ and $T$ were increased and decreased after castration, respectively. However, the content of $G n R H-I$ mRNA was unaltered in castration roosters, which corroborated the results of Wiemann et al. (1990). These results suggest that increased in serum LH and FSH concentrations accompany with up-regulating levels of $L H \beta$ and FSH $\beta$ mRNA after castration is not depended on GnRH synthesis in the hypothalamus. There are other factors can explain increased LH and FSH secretion after castration. Katt et al. (1985) reported that castration increased pituitary sensitivity to GnRH by increasing GnRH receptor number. We further examined GnRHR mRNA in pituitary among the two groups and found that GnRHR mRNA did not differ between the two groups. Thus, increased pituitary sensitivity to GnRH after castration cannot account for the rise in gonadotropins. However, the present data do not exclude potential roles in conversion of precursor pro-GnRH to the mature bioactive $\mathrm{GnRH}$ decapeptide or in rate of degradation of pro-GnRH.

Gonadal hormones also can regulate gonadotropin subunit gene expression by acting directly on the pituitary gonadotropes. It is well-known that estrogens and androgens influence pituitary functions by binding to the corresponding receptors in pituitary. Sun et al. (2012) reported that ER $\alpha$ and AR was expressed in LH cells about $68 \%$ and $37 \%$, respectively, in pituitary of adult cockerels. They also deduced that ER and AR-positive cells (approximately 64\%) are FSH-secreting gonadotrope. The present study showed that levels of $E R \alpha$ and $A R$ mRNA were decreased and increased, respectively, in capons. We speculated that the increased serum LH and FSH levels parallelly change levels of $L H \beta$ and $F S H \beta$ mRNA in pituitary after castration, which could be associated with decreasing $E R \alpha$ and increasing $A R$ mRNA levels in pituitary gland but the related mechanisms need to be investigated in future study. Additionally, the expression of $F S H \beta$ gene and secretion of FSH also appeared to be modulated by local production (Activin and FS) (Winters et al., 2001). Activin is produced by the gonads and gonadotropes. Activin works through specific activin receptors to stimulate FSH synthesis (Carroll et al., 1989; Huang et al., 2001) FS is produced by the gonads, gonadotropes, and folliculo-stellate cells. FS inhibits expression of $F S H \beta$ mRNA by binding to and neutralizing activin (Shimonaka et al., 1991). We found that levels of FS mRNA decreased in castrated chickens. However, Popovics et al. (2011) reported that FS mRNA was increased by $57 \%$ compared with sham-operated rats and Winters et al. (2001) found that FS mRNA remain unaffected in castrated adult male rhesus monkeys. The reasons for these discrepancies could be attributed to difference in species. These findings suggest that increased the FSH $\beta$ mRNA and serum FSH are also associated with the decreasing of $F S$ mRNA in pituitary glands of castrated roosters.

\section{Conclusion}

The present study suggests that increased LH and FSH in serum and mRNA levels in pituitary after castration are not depended on GnRH synthesis. Our data also suggest that changed expression of $E R \alpha, A R$ and $F S$ genes in the pituitary gland may be important components of regulating gonadotropin in capons

\section{Acknowledgments}

This work was supported by grants from the China $\mathrm{S} \& \mathrm{~T}$ Pillar Program (No. 2011BAD28B03) and the '863' Program of China (No. 2011AA100305).

\section{References}

Bruggeman V, Onagbesan O, Vanmontfort D, Berghman L, Verhoeven $\mathrm{G}$ and Decuypere E. Effect of long-term food restriction on pituitary sensitivity to CLHRH-I in broiler breeder females. Journal of Reproduction and Fertility, 114: 267-276. 1998.

Burger LL, Haisenleder DJ, Dalkin AC and Marshall JC. Regulation of gonadotropin subunit gene transcription. Journal of Molecular Endocrinology, 33: 559-584. 2004.

Carroll RS and Baum MJ. Evidence that oestrogen exerts an equivalent negative feedback action on $\mathrm{LH}$ secretion in male and female ferrets. Journal of Reproduction and Fertility, 86: 235-245. 1989.

Contijoch AM, Malamed S, McDonald JK and Advis JP. Neuropeptide $\mathrm{Y}$ regulation of LHRH release in the median eminence: immunocytochemicaland physiological evidence in hens. Neuroendocrinology, 57: 135-145. 1993.

Dalkin AC, Haisenleder DJ, Ortolano GA, Suhr A and Marshall JC. Gonadal regulation of gonadotropin subunit gene expression: evidence for regulation of follicle-stimulating hormone- $\beta$ messenger ribonucleic acid by nonsteroidal hormones in female rats. Endocrinology, 127: 798-806. 1990.

Dalkin AC, Paul SJ, Haisenleder DJ, Ortolano GA, Yasin M and Marshall JC. Gonadal steroids effect similar regulation of gonadotrophin subunit mRNA expression in both male and female rats. Journal of Endocrinology, 132: 39-45. 1992.

Guémené D and Williams JB. In-vitro and in-vivo responses to chicken LHRH-I and chicken LHRH-II in male turkeys (Meleagris gallopavo). Journal of Endocrinology, 132: 387393. 1992.

Huang HJ, Sebastian J, Strahl BD, Wu JC and Miller WL. Transcriptional regulation of the ovine follicle-stimulating hormone- $\beta$ gene by activin and gonadotropin-releasing hormone $(\mathrm{GnRH})$ : involvement of two proximal activator protein-1 sites for GnRH stimulation. Endocrinology, 142: 2267-2274. 2001.

Kameda Y, Miura M and Nishimaki T. Localization of neuropeptide Y mRNA and peptide in the chicken hypothalamus and their alterations after food deprivation, dehydration, and castration. Journal of Comparative Neurology, 436: 376-388. 2001.

Katt JA, Duncan JA, Herbon L, Barkan A and Marshall JC. The 
frequency of gonadotropin-releasing hormone stimulation determines the number of pituitary gonadotropin-releasing hormone receptors. Endocrinology, 116: 2113-2115. 1985.

Livak KJ and Schmittgen TD. Analysis of relative gene expression data using real-time quantitative PCR and the 2(-Delta Delta C (T)) Method. Methods, 25: 402-408. 2001.

Maney DL, Richardson RD and Wingfield JC. Central administration of chicken gonadotropin-releasing hormone-II enhances courtship behaviour in a female sparrow. Hormones and Behavior, 32: 11-18. 1997.

Millam JR, Ottinger MA, Craig-Veit CB, Fan Y, Chaiseha Y and El Halawani M. Multiple forms of GnRH are released from perifused medial basal hypothalamic/preoptic area (MBH/ POA) explants in birds. General and Comparative Endocrinology, 111: 95-101. 1998.

Millam JR, Wang R, Craig-Veit CB and Siopes TD. Apposition of enkephalinergic axons with cGnRH I-containing perikarya in turkey hen brain. General and Comparative Endocrinology, 127: 128-135. 2002.

Miyamoto K, Hasegawa Y, Nomura M, Igarashi M, Kangawa K and Matsuo H. Identification of the second gonadotropin-releasing hormone in chicken hypothalamus: Evidence that gonadotropin secretion is probably controlled by two distinct gonadotropinreleasing hormones in avian species. Proceedings of the National Academy of Sciences of the United States of America, 81: 3874-3878. 1984.

Petrowski ML, Wong EA, Ishii S and EL Halawani ME. Influence of Ovariectomy and Photostimulation on Luteinizing Hormone in the Domestic Turkey: Evidence for Differential Regulation of Gene Expression and Hormone Secretion. Biology of Reproduction, 49: 295-299. 1993.

Popovics P, Rekasi Z, Stewart AJ and Kovacs M. Regulation of pituitary inhibin/activin subunits and follistatin gene expression by $\mathrm{GnRH}$ in female rats. Journal of Endocrinology, 210: 7179. 2011.

Proudman JA, Vandesande F and Berghman LR. Immunohistochemical evidence that follicle-stimulating hormone and luteinizing hormone reside in separate cells in the chicken pituitary. Biology of Reproduction, 60: 1324-1328. 1999.

Proudman JA, Scanes CG, Johannsen SA, Berghman LR and Camp MJ. Comparison of the ability of the three endogenous GnRHs to stimulate release of follicle-stimulating hormone and luteinizing hormone in chickens. Domestic Animal Endocrinology, 31: 141-153. 2006.
SAS Institute SAS/STAT User's Guide: Statistics. Version 9.1. SAS Institute Inc., Cary, NC. 2003.

Sharp PJ, Talbot RT, Main GM, Dunn IC, Fraser HM and Huskisson NS. Physiological roles of chicken LHRH-I and -II in the control of gonadotrophin release in the domestic chicken. Journal of Endocrinology, 124: 291-299. 1990.

Shimonaka M, Inouye S, Shimasaki S and Ling N. Follistatin binds to both activin and inhibin through the common subunit. Endocrinology, 128: 3313-3315. 1991.

Stansfield SC and Cunningham FJ. Modulation by endogenous opioid peptides of the secretion of LHRH from cockerel (Gallus domesticus) mediobasal hypothalamic tissue. Journal of Endocrinology, 114: 103-110. 1987.

Sun DH, Cui TT, Luo HS, Li RG, Cui S and Liu JL. Cell-specific distributions of estrogen receptor alpha $(\mathrm{ER} \alpha)$ and androgen receptor (AR) in anterior pituitary glands from adult cockerels as revealed by immunohistochemistry. Cell and Tissue Resarch, 348: 551-558. 2012.

Terada O, Shimada K and Saito N. Effect of oestradiol replacement in ovariectomized chickens on pituitary LH concentrations and concentrations of mRNAs encoding LH beta and alpha subunits. Journal of Reproduction and Fertility, 111: 59-64. 1997.

Van Gils J, Absil P, Grauwels L, Moons L, Vandesande F, and Balthazart J. Distribution of luteinizing hormone-releasing hormones I and II (LHRH-I and -II) in the quail and chicken brain as demonstrated with antibodies directed against synthetic peptides. Journal of Comparative Neurology, 334: 304323. 1993.

Wiemann JN, Clifton DK and Steiner RA. Gonadotropin-releasing hormone messenger ribonucleic acid levels are unaltered with changes in the gonadal hormone milieu of the adult male rat. Endocrinology, 127: 523-532. 1990.

Wilson SC and Sharp PJ. Induction of luteinizing hormone release by gonadal steroids in the ovariectomized domestic hen. Journal of Endocrinology, 71: 87-98. 1976.

Winters SJ, Kawakami S, Sahu A and Plant TM. Pituitary follistatin and activin gene expression, and the testicular regulation of FSH in the adult rhesus monkey (Macaca mulatta). Endocrinology, 142: 2874-2878. 2001.

Zadworny D and Etches RJ. Effects of Ovariectomy or Force Feeding on the Plasma Concentrations of Prolactin and Luteinizing Hormone in Incubating Turkey Hens. Biology of Reproduction, 36: 81-88. 1987. 